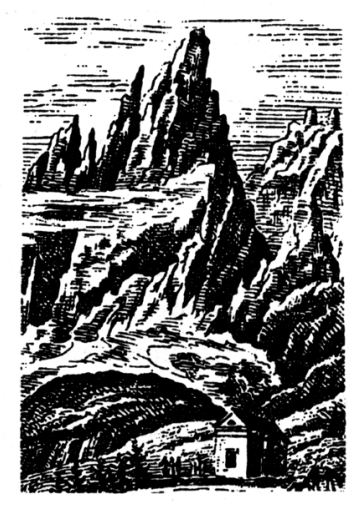

\title{
Justyna Mokras-Grabowska
}

Uniwersytet Łódzki

justyna.mokras_grabowska@op.pl

Sławoj Tanaś

Uniwersytet Łódzki

slatan@geo.uni.lodz.pl

DOI: $10.19195 / 2084-4107.11 .21$

\section{Mit elitarności w turystyce kwalifikowanej. Przykład Tatrzańskiego Parku Narodowego}

Słowa-klucze: Tatrzański Park Narodowy, turystyka kwalifikowana, statystyka, kultura

Keywords: Tatra National Park, adventure tousism, statistics, culture

\section{The myth of elitism in qualified tourism. The example of the Tatra National Park}

\section{Summary}

Qualified tourism, understood as the highest form of tourism, the most perfect kind of conscious tourism, was introduced and popularised in Poland in the 1950s by the PTTK (Polish 
Tourism and Sightseeing Society). Combined with a knowledge of the so-called tourism culture, pursued with passion and expertise, today it concerns a relatively small, ambitious group of active tourists having very precise interests and seeking the highest form of tourist specialisation. The considerable demands for the participants means that the term "qualified tourism" is increasingly replaced with the term "active tourism" available to a broader section of society. The phenomenon is associated with socio-economic and cultural transformations, including the postmodern commercialisation of leisure time. Forms of outdoor recreation are becoming more and more accessible, while transformations of lifestyle, amount of free time and ways of spending it influence tourists' preferences and tourist activities. What is also significant is the fashion for active leisure created in recent years by the media. Such a "simplified", pop-cultural approach to active tourism contributes to reckless and irresponsible behaviours of tourists, as is perfectly illustrated by what happens in the Tatra National Park. Despite the fact that it is a fairly small part for European standards, it is one of the "busiest" in terms of tourist traffic. In its highest season (July and August) its visitors include both conscious tourists appropriately prepared for mountain hiking (including qualified tourists) and "casual" tourists, motivated mainly by their unreflecting need to "do" the most popular sites in Poland's highest mountains.

The authors of the article discuss the specificity of qualified tourism and refer to examples of hikers visiting the Tatra National Park in the highest summer season. They demonstrate the elitist nature of the principles of qualified tourism and thus refer to the practice, i.e. behaviour of tourists. In this they point to the lack of boundaries in the exploration of Poland's highest mountains as well as their demystification.

\section{Wprowadzenie}

Aby odpowiednio przeżywać turystykę, potrzebna jest niewątpliwie wysoka świadomość turystyczna - rozumienie środowiska, w którym dana aktywność się odbywa, oraz szacunek do niego, a także świadomość własnych działań w tym środowisku odzwierciedlająca wiedzę merytoryczną i techniczną turysty. Szczególnego znaczenia pojęcie tak rozumianej świadomości nabiera w wypadku turystyki aktywnej, w tym pieszej górskiej, która wymaga wysokich umiejętności, zdawania sobie sprawy z zagrożeń, odpowiedzialności oraz autentycznego doznawania przeżywanych treści.

W czasach gdy dostępność niemal każdej formy aktywności rekreacyjnej jest na wyciągnięcie ręki, o takie podejście do turystyki coraz trudniej. Obok osób wędrujących z pasją, przygotowanych, kulturalnych i odpowiedzialnych, na turystycznym szlaku pojawiają się coraz częściej osoby przypadkowe, nieznające przestrzeni, w której się poruszają, a także „zaliczające” tzw. żelazne punkty obszarów uznawanych za najbardziej atrakcyjne turystycznie. Taką właśnie przestrzenią są Tatry, a w szczególności obszar je chroniący i tym samym przyczyniający sią do znacznej koncentracji ruchu turystycznego - Tatrzański Park Narodowy. Region ten ma odległe tradycje turystyczne sięgające przełomu XVIII i XIX w., kiedy to był odwiedzany przede wszystkim przez amatorów piękna gór. $Z$ czasem jego popularność rosła, a indywidualny ruch turystyczny przybrał charakter masowy, przyczyniając się do wielu negatywnych zjawisk zarówno w środowisku przyrodniczym i kulturowym regionu, jak 
i w samej turystyce, której nadrzędną ideą powinny być funkcje wychowawcze, edukacyjne i poznawcze. Mit elitarności najwyższych polskich gór zaczął więc powoli zanikać, stały się one dostępne dla każdego, obecnie coraz rzadziej można się również spotkać z kulturą turystyczną na wysokogórskim szlaku czy w obiektach turystycznych. Jaka jest wobec tego w polskich Tatrach aktualność idei turystyki kwalifikowanej uznawanej za „matkę turystyki”? Jacy turyści wędrują latem po tatrzańskich szlakach? Artykuł jest próbą odpowiedzi na te pytania.

\section{Motywacje w turystyce pieszej górskiej dawniej i obecnie}

W dobie przemian społeczno-gospodarczych i kulturowych ostatnich lat, którym towarzyszy postmodernistyczna komercjalizacja czasu wolnego, świadomość w turystyce wydaje się tematem niezwykle istotnym. Formy aktywności w zakresie rekreacji plenerowej stają się coraz łatwiej dostępne, a przemiany dotyczące stylu życia, ilości czasu wolnego i sposobów jego spędzania mają wpływ na preferencje turystów oraz przebieg pobytu turystycznego (Niezgoda 2013, s. 90-91; Prószyńska-Bordas 2013, s. 65). Nie bez znaczenia pozostaje także pojawiająca się w ostatnich latach i kreowana przez media moda na aktywny wypoczynek. Uczestnictwo w nim nie zawsze jednak idzie w parze $\mathrm{z}$ odpowiednim przygotowaniem psychofizycznym, odpowiedzialnością czy znajomością zasad zachowania się na turystycznym szlaku.

Obszary górskie w porównaniu z obszarami niżej położonymi były zawsze mało przyjazne i trudno dostępne dla człowieka (Ciapała, Zielonka, Kmiecik-Wróbel 2010, s. 67). Pierwsze wyprawy w Tatry wiązały się z poszukiwaniem skarbów i wędrówkami pasterzy. Z biegiem lat zaczęło tu jednak przybywać coraz więcej osób - amatorów piękna, artystów. Początki turystyki w Tatrach miały zatem charakter indywidualny, jednak z czasem ruch turystyczny omawianego regionu przybrał formę masową.

Próby usystematyzowania motywów uprawiania turystyki pieszej górskiej (w tym taternictwa) podejmowano już na początku XX w. (Czyż 2010, s. 242). Wyróżniono wówczas trzy grupy motywów: poznawcze, estetyczne i sportowe. W wypadku motywów sportowych dominującym był tzw. pierwiastek ruchu, w tym także dążności odkrywcze, chęć przeżywania przygód, żądza zmierzenia się z trudnościami i niebezpieczeństwem gór, potrzeba zwycięstwa i walki z samym sobą. Z kolei pobudki estetyczne wiązały się z pięknem i harmonią świata górskiego, ciszą i samotnością - a więc czynnikami wpływającymi na życie wewnętrzne człowieka. Kontynuując badania nad przyczynami wędrowania po górach, z czasem zaczęto odwoływać się jednak głównie do motywów sportowych. W okresie dwudziestolecia międzywojennego zwrócono jednak uwagę na pewną „otoczkę metafizyczną” gór, która jednych przyciąga, a drugich 
odpycha. Z czasem znaczenia nabrał zatem romantyczny kult widoku i piękna przyrody górskiej, a także chęć eksploracji „nieznanego” — czegoś przyciągającego, pobudzającego do działania, wysiłku i odkrywania świata.

Na przełomie XX i XXI w. struktura motywacyjna uległa niemal całkowitej przemianie, co wiąże się z coraz bardziej urozmaiconą i powszechnie dostępną ofertą, popularyzacją aktywnego stylu życia przez media (w tym modą na uprawianie ekstremalnych form rekreacji), a także ze stanami przeciążenia psychofizycznego w życiu codziennym. Jak podaje Jan Fenczyn (2000), hierarchia motywów uprawiania turystyki górskiej kształtuje się następująco: motywy zdrowotne, emocjonalne, katartyczne, aktywnościowe, poznawcze, społeczne i ambicyjne (ambicjonalne). Warto jednak podkreślić, że w różnych obszarach w zależności od badanej grupy społecznej hierarchia ta ulega zaburzeniom. Coraz częściej bowiem głównego znaczenia nabiera motywacja emocjonalna i katartyczna, wiążąca się w tym wypadku z chęcią odcięcia się od codzienności i życiowych problemów (eskapizm). Tak znacząca rola motywacji emocjonalnej podyktowana jest chęcią rozładowania nagromadzonych na co dzień emocji. U źródeł motywacji katartycznej leżą z kolei potrzeby związane z brakiem wypoczynku, stany przeciążenia psychicznego człowieka oraz działanie stresu. Podczas górskich wędrówek istnieją także korzystne warunki do powstawania syntonii - współbrzmienia emocjonalnego z innym człowiekiem. Odmienne otoczenie, trudy marszu, cenne środowisko przyrodnicze i pokonywanie własnych słabości sprzyjają odprężeniu oraz emocjonalnemu otwarciu na drugiego człowieka.

\section{Idea turystyki kwalifikowanej}

W latach pięćdziesiątych XX w. w środowisku PTTK powstał termin turystyki kwalifikowanej, nazywanej przez wiele następnych lat „matką turystyki” czy też turystyką sensu stricto, a nawet „turystyką właściwą” (Łobożewicz 1983, s. 7). Pojawienie się terminu miało związek z próbą wspólnego określenia nowych, powstających po drugiej wojnie światowej w socjalistycznej Polsce dziedzin turystyki, które wymagały specjalistycznego sprzętu i umiejętności (kwalifikacji). Nawiązano w ten sposób do istotnych w okresie powojennym idei krajoznawczych, które uznano za część kultury społecznej. Powszechną troską władz politycznych, administracyjnych i organizacji społecznych było bowiem upowszechnianie krajowej turystyki kwalifikowanej (Łobożewicz, 1983, s. 11). Poprzez jej uprawianie można było realizować zarówno cele rekreacyjno-zdrowotne, jak i poznawcze. Imprezy krajoznawczo-turystyczne stanowiły poza tym najlepszą okazję do realizacji zadań związanych z ,wychowaniem społeczeństwa”.

Turystyka kwalifikowana do dziś uważana jest za najwyższą formę specjalizacji turystycznej w wybranej dyscyplinie, oznacza turystykę uprawianą ze znawstwem i pasją, a także $\mathrm{z}$ odpowiednim przygotowaniem technicznym 
i merytorycznym. Obecnie, w dobie coraz większej popularyzacji aktywności fizycznej, pojęcie turystyki kwalifikowanej staje się coraz mniej czytelne. Jej cechy związane zarówno z doskonaleniem kwalifikacji osobowych, jak i kwalifikowaniem osiągnięć turystycznych wydają się jednak niezwykle istotne i nadal aktualne. Takie podejście do uprawiania turystyki aktywnej oznacza bowiem w praktyce wiedzę z zakresu uprawianej dziedziny, a także znajomość obszaru będącego przedmiotem eksploracji turystycznej i zdawanie sobie sprawy z podejmowanej formy aktywności w danym terenie. To także chęć kwalifikowania własnych osiągnięć oraz zdobywanie adekwatnej wiedzy. Mimo że w początkowym okresie popularyzacji turystyki kwalifikowanej przez PTTK kładziono w niej nacisk głównie na zdobywanie coraz wyższych odznak turystycznych w wybranej dziedzinie turystyki aktywnej, wiele jej pozostałych cech zasługuje na szczególną uwagę. System odznak, który stał się instrumentem upowszechniania turystyki i krajoznawstwa, a także symbolem sprawności i wiedzy (Mokras-Grabowska 2015, s. 348) to tylko jeden z nielicznych elementów wyróżniających turystykę kwalifikowaną. Oznacza ona przede wszystkim świadome uczestnictwo w wybranej dziedzinie plenerowej turystyki aktywnej, przygotowanie, osiąganie celów perfekcyjno-sprawnościowych i poznawczych oraz rozwijanie zainteresowań. Istotne są w tym wypadku takie kwestie, jak: odporność i zahartowanie na trudy, umiejętność posługiwania się sprzętem turystycznym oraz wiedza z zakresu odpowiedniego (kulturalnego, odpowiedzialnego) zachowania na szlaku czy w obiekcie turystycznym. To aktywna postawa poznawcza, samodzielność i chęć poszerzania wiedzy o regionie. Wszystko to składa się na swego rodzaju kulturę turystyczną, która stanowi nieodzowny atrybut turysty kwalifikowanego.

Tak wysokie wymagania wobec uczestników powodują jednak, że aktualnie coraz częściej termin ten zastępowany jest „łagodniejszym” w formie określeniem - turystyka aktywna, a sama turystyka kwalifikowana dotyczy niezbyt licznej, ambitnej grupy turystów.

Kwalifikacje i przygotowanie nabierają szczególnego znaczenia w środowisku górskim, w którym turysta będzie zmagał się z trudami wędrówki oraz uciążliwymi i zmiennymi warunkami meteorologicznymi. Coraz częściej, oprócz turystów przygotowanych i odpowiedzialnych pojawiają się turyści „przypadkowi” — z reguły nieprzygotowani zarówno pod względem sprzętu turystycznego, jak i umiejętności - którzy traktują góry jako pole do podniesienia swojego statusu społecznego i prestiżu poprzez „zaliczanie” kolejnych sztandarowych miejsc. Taki turysta wybiera się w podróż po „ładne widoki”, znane mu już z przekazów medialnych o uproszczonej z reguły formie (Frydryczak 2007, s. 105-106). Zjawisko to prowadzi do wielu brawurowych, śmiałych i zuchwałych zachowań. Rezultatem tego są liczne wypadki, które stanowią efekt tego, że znaczna cześć turystów nie ma świadomości ryzyka i możliwych konsekwencji związanych z uprawianiem turystyki na obszarach górskich (Wolski 2010, s. 75). Dochodzi zatem do zjawiska zwanego demistyfikacją gór - obszar górski przestaje być niedostępny i zarezerwowany jedynie dla eli tarnej gr u py turys tó w. Góry 
przestają być kojarzone z wielką przygodą zarezerwowaną dla nielicznych, stają się obszarem „dla wszystkich”.

\section{Specyfika ruchu turystycznego w Tatrzańskim Parku Narodowym w okresie najwyższej frekwencji (sezon letni)}

Tatrzański Park Narodowy (TPN) w skali Europy należy do parków o niewielkiej powierzchni, a jednocześnie do najbardziej „obciążonych” ruchem turystycznym (Pociask-Karteczka, Baścik, Czuberant 2007, s. 272). Wskaźnik obciążenia szlaków turystycznych przewyższa tu wielokrotnie wskaźniki obciążenia ruchem obszarów górskich w innych krajach europejskich. Urozmaicone środowisko przyrodnicze, łatwa dostępność i zadowalająca infrastruktura turystyczna sprawiają, że należy on do najczęściej odwiedzanych parków narodowych w Polsce. Jak podaje Dominik Wolski (2010, s. 75), każdego roku TPN odwiedzają rzesze turystów oraz osób, które z górami wiąże pasja lub wykonywany zawód - wspinacze, przewodnicy, ratownicy górscy oraz sami pracownicy parku. Tak duża skala ruchu, obejmująca osoby o różnym stopniu przygotowania, powoduje, że nie jest możliwe uniknięcie wypadków. Najczęstszą ich przyczyną jest brak przygotowania, w tym brak planu wędrówki, odpowiedniego stroju czy też prowiantu.

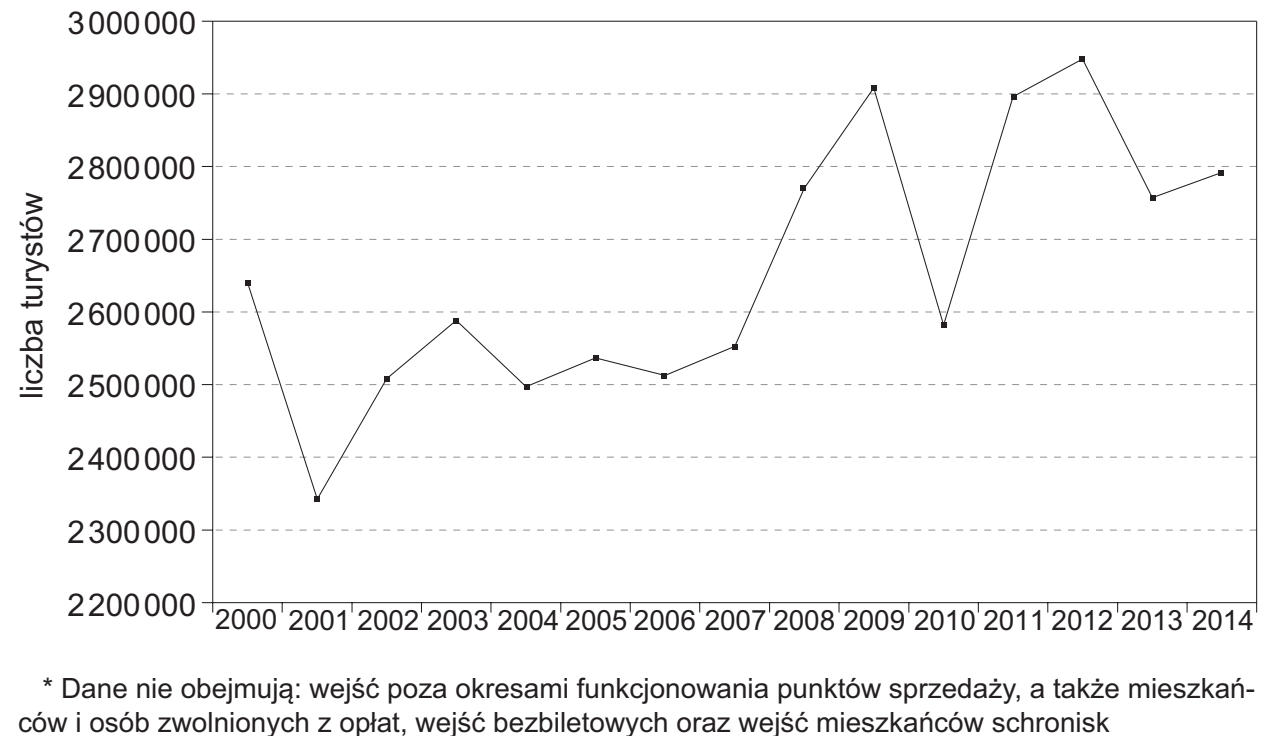

Wykres 1. Wielkość ruchu turystycznego w Tatrzańskim Parku Narodowym w latach 2000-2014 Źródło: opracowanie własne na podstawie danych TPN. 
Frekwencja zwiedzających parki narodowe w Polsce jest zróżnicowana i waha się od około 10 tys. do ponad 2,5 mln osób (Partyka 2010, s. 13). Tatrzański Park Narodowy stanowi obszar o najwyższej frekwencji, kolejne to: Karkonoski ( $2 \mathrm{mln}$ ) oraz Woliński $(1,5 \mathrm{mln})$.

Ponadto ruch turystyczny w polskich Tatrach odznacza się silną koncentracją czasową (lipiec, sierpień) i przestrzenną (Palenica Białczańska, Dolina Kościeliska). Charakteryzuje go znaczne przekroczenie chłonności i pojemności turystycznej oraz przepustowości szlaków. Jak wynika z danych statystycznych TPN, na przestrzeni lat 2000-2014 ruch ten ulegał wahaniom, osiągając najwyższe wartości w roku 2012 (2 947949 turystów)1 (wykres 1). W 2014 r. park odwiedziło 2791837 turystów.

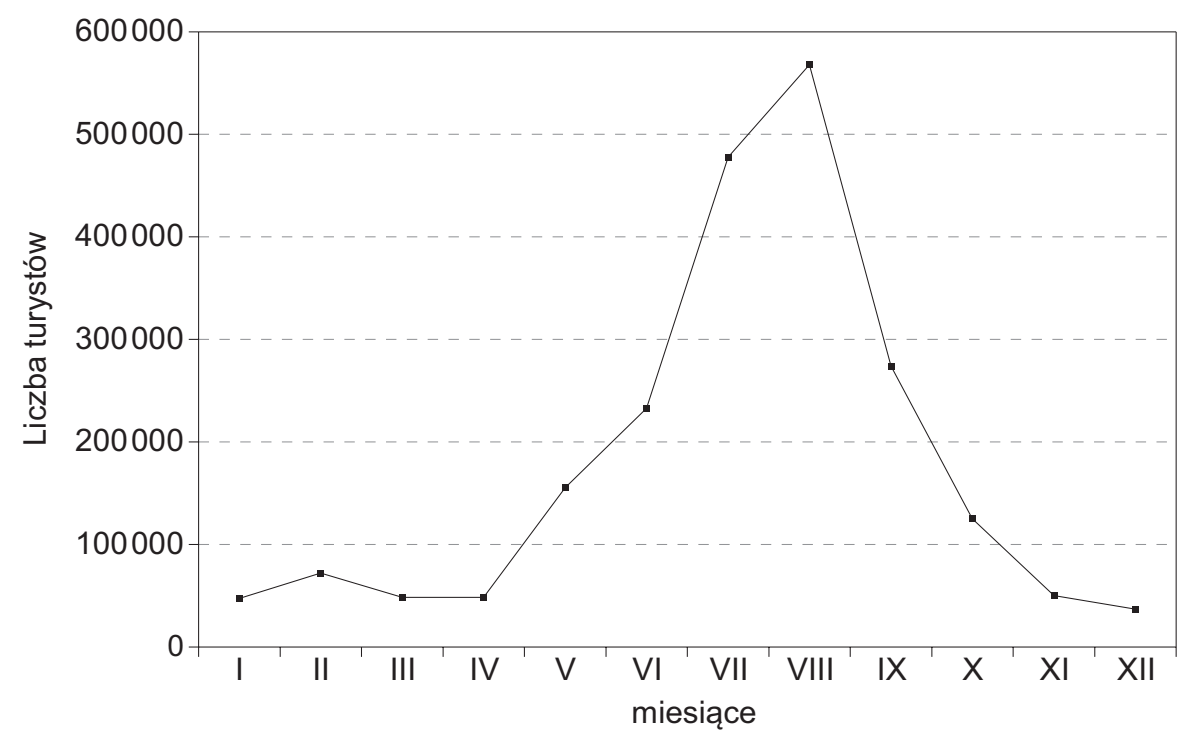

* Dane nie obejmują: danych Wspólnoty Leśnej w Witowie, danych PKL, wejść poza okresami funkcjonowania punktów sprzedaży, wejść mieszkańców i osób zwolnionych z opłat, wejść bezbiletowych oraz wejść mieszkańców schronisk

Wykres 2. Wielkość ruchu turystycznego w Tatrzańskim Parku Narodowym w 2014 r. według miesięcy

Źródło: opracowanie własne na podstawie danych TPN.

Jak wynika z wykresu 2, ruch turystyczny w skali roku odznacza się wyraźną sezonowością: najwięcej odwiedzin przypada na miesiące letnie, zwłaszcza na sierpień — 567929 turystów. Taki rozkład ruchu turystycznego wiąże się zapewne z faktem, że w okresie letnim teren Parku jest najbardziej dostępny, a czas urlopowo-wakacyjny sprzyja odwiedzinom zarówno turystów indywidualnych, jak i grup zorganizowanych. W półroczu zimowym podwyższonym ruchem tu-

1 https://www.tpn.pl (dostęp: 10.10.2016). 
rystycznym wyróżnia się luty, związany przede wszystkim z organizacją turystyki grupowej w okresie ferii zimowych. Warto jednak podkreślić, że ze względu na bogatą ofertę infrastruktury narciarskiej u podnóża Tatr wielu turystów nie wkracza wówczas na obszar parku. Wakacyjny rekord turystycznej frekwencji przypada z reguły na długi weekend pomiędzy 15 a 17 sierpnia. W większości parków narodowych w Polsce ruch turystyczny ma charakter wybitnie sezonowy, jednak to właśnie Tatrzański Park Narodowy (wraz z Karkonoskim PN) jest tym wyjątkiem, gdzie występuje on cały rok (Partyka 2010, s. 15).

Ciekawych spostrzeżeń dostarcza także analiza wejść na teren Tatrzańskiego Parku Narodowego w wybranych punktach biletowych (wykres 3). Zauważalna jest tu znaczna dominacja punktu w Łysej Polanie (Palenica Białczańska), gdzie w 2014 r. na podstawie sprzedanych biletów odnotowano 722164 wejść. Zjawisko to ma związek przede wszystkim z masowym ruchem turystycznym na szlaku Palenica Białczańska - Morskie Oko, gdzie liczba dziennych odwiedzin podczas wakacyjnych weekendów wynosi blisko 10 tys. Drugim najliczniej odwiedzanym miejscem jest Dolina Kościeliska (447 925 sprzedanych biletów).

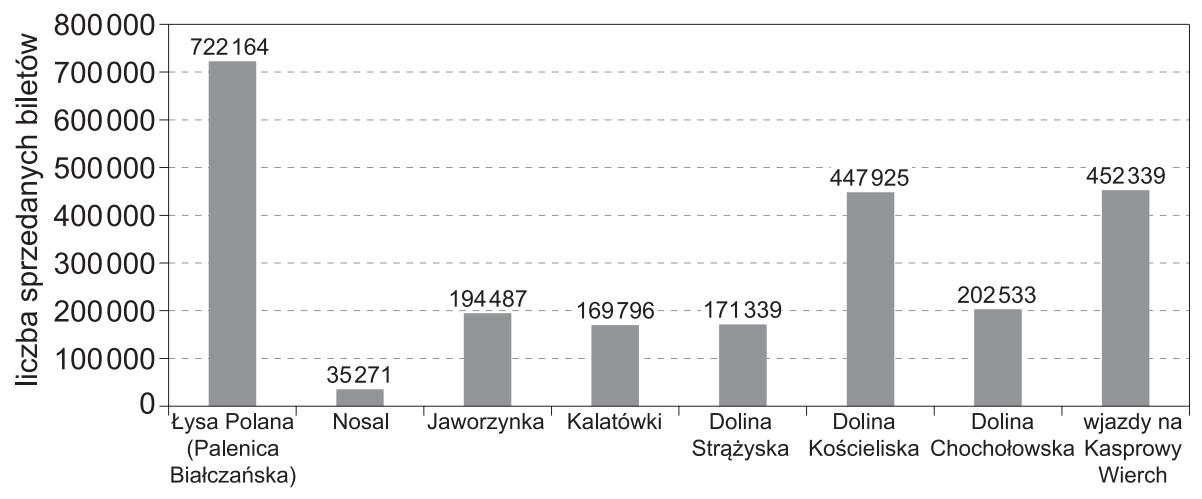

*Dane nie obejmują: danych Wspólnoty Leśnej w Witowie, danych PKL, wejść poza okresami funkcjonowania punktów sprzedaży, wejść mieszkańców i osób zwolnionych z opłat, wejść bezbiletowych oraz wejść mieszkańców schronisk

Wykres. 3. Liczba sprzedanych biletów wstępu na teren Tatrzańskiego Parku Narodowego w 2014 r. wg wybranych punktów biletowych

Źródło: opracowanie własne na podstawie danych TPN.

Masowość ruchu turystycznego w polskich Tatrach ma swoje konsekwencje. Powszechna opinia, że w Tatry powinien i może wybrać się każdy, bez względu na możliwości psychofizyczne i przygotowanie przyczynia się do wielu brawurowych zachowań, a co za tym idzie - licznych (często bardzo groźnych) wypadków.

$\mathrm{Z}$ danych udostępnionych przez Tatrzańskie Ochotnicze Pogotowie Ratunkowe wynika, że w 2015 r. w sezonie letnim (1 lipca-30 września) wszystkich działań ratowniczych podjętych przez TOPR na terenie Tatr było 274, z czego 89 z udziałem śmigłowca (tabela 1). W skali całego 2015 r. odbyło się 576 działań ratowniczych, 
w tym 173 z udziałem śmigłowca. W całym 2015 r. w polskiej części Tatr miało miejsce 13 wypadków śmiertelnych.

Wśród działań podjętych w sezonie letnim odbyło się 101 wypraw i 169 akcji ratunkowych. Dane te dotyczą tylko pomocy udzielanej turystom. W ramach wypraw alpinistycznych dodatkowo odbyło się jedynie 12 działań ratowniczych. Łącznie w omawianym okresie zaangażowanych do działań ratunkowych było 942 ratowników (tabela 2). Odnotowano 3 zdarzenia śmiertelne w wyniku zachorowań oraz upadku z wysokości. W skali całego roku upadek z wysokości był również dominującą przyczyną śmierci turystów w Tatrach (7), kolejną były lawiny (3) oraz zachorowanie (3).

Tabela 1. Liczba działań ratowniczych TOPR w Tatrach w okresie 1 lipca-30 września 2015

\begin{tabular}{|l|c|}
\hline Rodzaj działań ratowniczych & Liczba \\
\hline Wyprawy ratunkowe & 101 \\
\hline Akcje ratunkowe & 169 \\
\hline Interwencje pozostałe & 4 \\
\hline Ogółem & 274 \\
\hline w tym z udziałem śmigłowca & 89 \\
\hline
\end{tabular}

Źródło: opracowanie własne na podstawie danych TOPR.

Tabela 2. Działania ratownicze TOPR w okresie 1 lipca-30 września 2015 - wybrane dane

\begin{tabular}{|l|c|}
\hline \multicolumn{1}{|c|}{ Dane } & Liczba \\
\hline Liczba ratowników w interwencji & 942 \\
\hline Liczba godzin pracy ratowników & 1985 \\
\hline Liczba zdarzeń śmiertelnych & 3 \\
\hline
\end{tabular}

Źródło: opracowanie własne na podstawie danych TOPR.

Tabela 3. Działania ratownicze TOPR w okresie 1 lipca-30 września 2015 — wybrane przyczyny zdarzeń

\begin{tabular}{|l|c|}
\hline \multicolumn{1}{|c|}{ Przyczyna } & Liczba \\
\hline Upadek (np. potknięcie) & 139 \\
\hline Upadek z wysokości & 13 \\
\hline Zabłądzenie & 20 \\
\hline Spadający kamień/lód & 8 \\
\hline Wpływ wysokiej temperatury & 5 \\
\hline
\end{tabular}

Góry, Literatura, Kultura 11, 2018

(C) for this edition by CNS 


\begin{tabular}{|l|c|}
\hline Zachorowanie & 89 \\
\hline Brak umiejętności & 22 \\
\hline Nieodpowiednie wyposażenie & 10 \\
\hline
\end{tabular}

Źródło: opracowanie własne na podstawie danych TOPR.

Analiza przyczyn działań ratowniczych TOPR w sezonie letnim 2015 pokazuje, że najczęściej ratownicy wzywani byli do zdarzeń określanych jako upadek - 139 (np. potknięcie na szlaku turystycznym) oraz zachorowanie - 89 (tabela 3). Częstym rodzajem wypadku były także: brak umiejętności (22), zabłądzenie (20), upadek z wysokości (13) oraz nieodpowiednie przygotowanie (10).

Dane te wskazują na bardzo swobodne traktowanie wędrówek wysokogórskich na obszarze TPN. Potwierdzają je również obserwacje własne autorów. Przygotowanie turystów tatrzańskich do odbywanej wędrówki zostało omówione w kolejnym punkcie.

\section{Kwalifikacje turystów pieszych górskich w Tatrzańskim Parku Narodowym — wyniki badań}

Badania ruchu turystycznego na obszarze Tatrzańskiego Parku Narodowego przeprowadzono w miesiącach letnich (lipiec, sierpień) 2015 r. w rejonie pięciu schronisk górskich PTTK: Schroniska „Murowaniec” na Hali Gąsienicowej, Schroniska na Hali Kondratowej, Schroniska w Roztoce, Schroniska na Polanie Chochołowskiej oraz Schroniska w Dolinie Pięciu Stawów Polskich.

Metodą badawczą był sondaż ankietowy, mający na celu analizę zachowań turystów pieszych górskich odwiedzających wybrane rejony polskiej części Tatr Wysokich i Zachodnich. W badaniu w sumie wzięło udział 540 osób - przeprowadzono po 120 wywiadów w rejonie każdego schroniska, z wyjątkiem schroniska w Roztoce, które ma odmienną specyfikę — nie jest położone w punkcie węzłowym szlaków turystycznych i tym samym nie stanowi bezpośredniej bazy wypadowej na górskie szlaki (w schronisku tym przeprowadzono 60 wywiadów kwestionariuszowych). Metodą doboru próby był dobór systematyczny, polegający na doborze jednostek według systemu liczbowego - co dziesiątego turysty.

W ocenie kwalifikacji respondentów poproszono o określenie w skali od 0 do 5 swoich umiejętności w turystyce pieszej górskiej. Poszczególne kwalifikacje zostały wybrane jako te najczęściej wymieniane w literaturze przedmiotu jako istotne w wypadku turystyki kwalifikowanej (Łobożewicz 1983, Merski 2002) i obejmowały: stycznej;

— znajomość doboru i obsługi sprzętu turystycznego oraz odzieży tury-

— korzystanie z nabytych przed wyjazdem map i przewodników;

— samodzielne poszukiwanie informacji o regionie; 
— samodzielne opracowanie tras wycieczek i orientację w terenie;

- sprawdzanie warunków atmosferycznych i sytuacji na szlakach turystycznych przed wyjściem;

— przygotowanie psychiczne i fizyczne do wyjazdu;

— odporność na trudy wędrówki górskiej;

— znajomość zasad zachowania się na szlaku i w obiekcie turystycznym;

— znajomość zasad bezpieczeństwa w turystyce pieszej górskiej.

W celu określenia znaczenia poszczególnych kwalifikacji dla respondentów obliczono $\mathrm{z}$ nich wartości średnie (średnia arytmetyczna). Jak wynika z wykresu nr 4, kwalifikacje średnio zostały ocenione dość wysoko (pomiędzy średnią 2,8 a 4,6), co może mieć związek z wysoką oceną własnych umiejętności przez respondentów oraz pewnego rodzaju brawurowym podejściem do turystyki górskiej w ogóle. Najwyżej w poszczególnych rejonach oceniono znajomość zachowania się na szlaku i w obiektach turystycznych (w tym najwyżej w schronisku w Roztoce — 4,6). Równie wysoko oceniono znajomość zasad bezpieczeństwa (w tym najwyżej w schroniskach „Murowaniec” i w Roztoce - średnia ocena - 4,5).

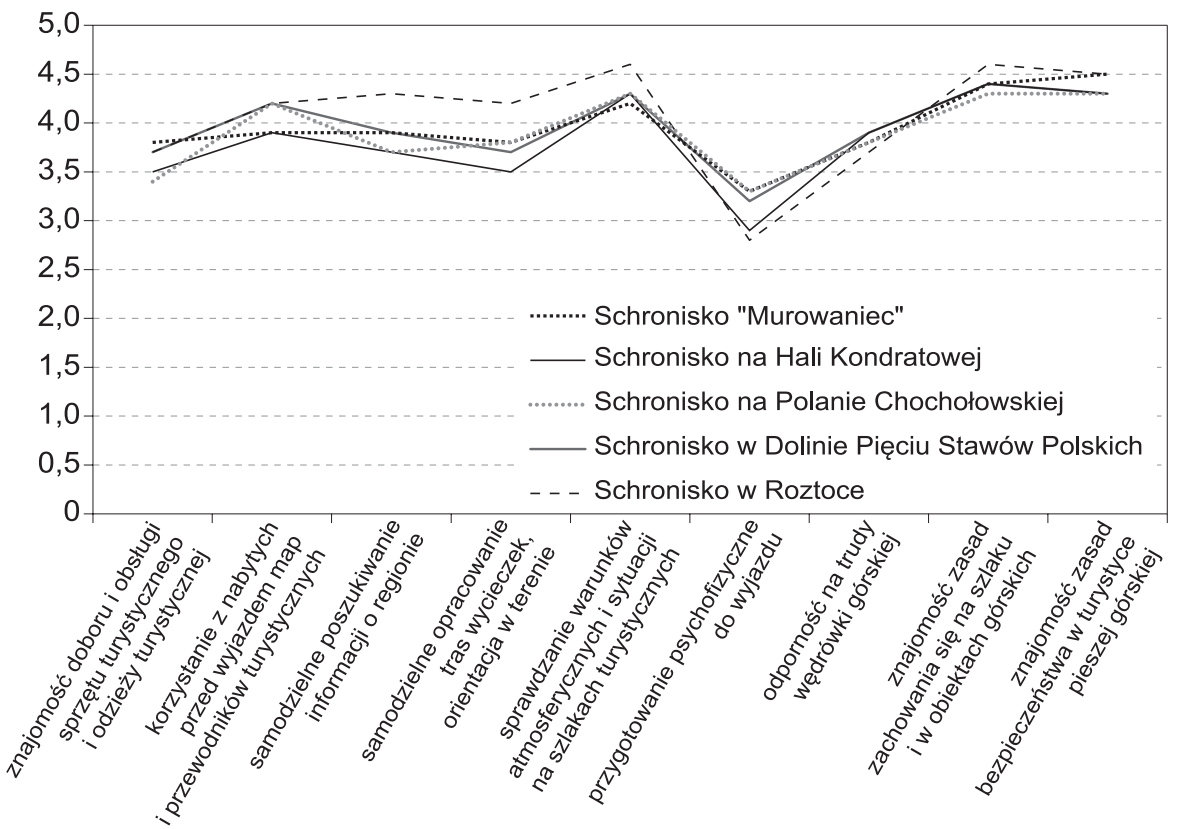

Wykres 4. Kwalifikacje respondentów z zakresu turystyki pieszej górskiej (średnia arytmetyczna)

Źródło: opracowanie własne na podstawie badań terenowych.

Najwyższe kwalifikacje charakteryzowały turystów poddanych badaniom w rejonie schroniska w Roztoce, z czego można wnioskować, że miejsce to odwiedzane jest przez turystów bardziej świadomych turystycznie, mających znaczne doświadczenie w turystyce pieszej górskiej. Usytuowanie schroniska na 
uboczu względem szlaków turystycznych powoduje, że nie docierają tu osoby „przypadkowe”, często także nie wiedząc o jego istnieniu.

W wypadku osób uprawiających wspinaczkę wysokogórską (8,5\% wszystkich respondentów), z których znaczna część (47,8\%) znalazła się wśród ankietowanych w rejonie schroniska „Murowaniec”, ocena kwalifikacji była dużo wyższa. Podobnie jak w wypadku pozostałych ankietowanych znajomość zasad zachowania się na szlaku i w obiekcie turystycznym, a także znajomość zasad bezpieczeństwa zostały ocenione najwyżej (średnie oceny w każdym wypadku - 4,6) (wykres 5). Wysoko oceniono także znajomość doboru i obsługi sprzętu turystycznego (średnia ocena 4,5), a także korzystanie z map i przewodników $(4,5)$, samodzielne opracowanie tras wycieczek i orientację w terenie $(4,5)$. Dużo wyższa ocena przypada na przygotowanie psychofizyczne do wyjazdu $(3,5)$ co wiąże się z pewnością ze zwiększonymi wymaganiami, specjalizacją i trudnością samej aktywności. Wyższa jest także odporność osób wspinających się na trudy wędrówki górskiej $(4,5)$. Warto przy tym dodać, że 50\% ankietowanych uprawiających wspinaczkę wysokogórską korzystało z noclegów w schroniskach górskich i niemal $40 \%$ deklarowało pobyt dłuższy niż tydzień. Aż 78,2\% respondentów odwiedziło rejon Orlej Perci uważanej za „obowiązkowy punkt" pobytu w polskich Tatrach. Jednak na podkreślenie zasługuje fakt, że jedynie $31 \%$ potrafiło zdefiniować pojęcie samej turystyki kwalifikowanej.

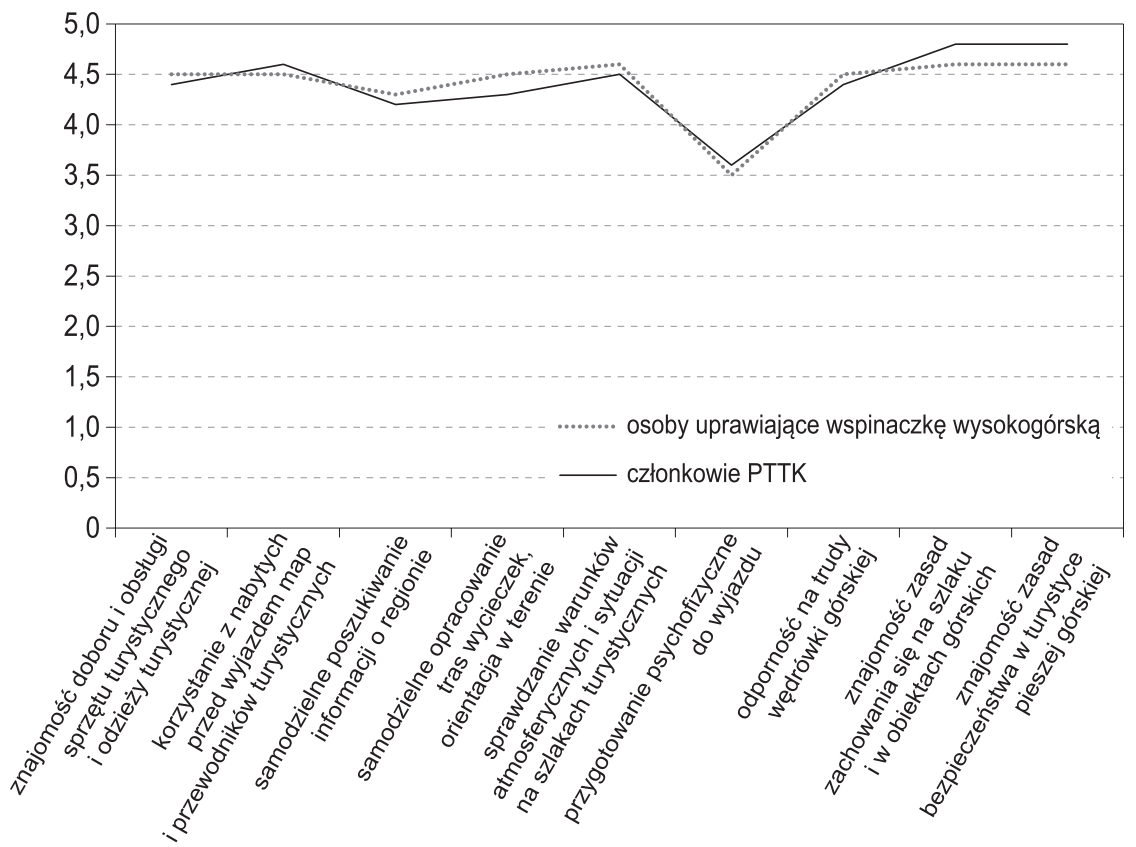

Wykres 5. Kwalifikacje z zakresu turystyki pieszej górskiej osób uprawiających wspinaczkę wysokogórską i członków PTTK (średnia arytmetyczna)

Źródło: opracowanie własne na podstawie badań terenowych.

W związku z tym, że termin ,turystyka kwalifikowana” został wprowadzony w latach pięćdziesiątych XX w. przez środowisko PTTK, warto również przyjrzeć Góry, Literatura, Kultura 11, 2018

(C) for this edition by CNS 
się turystom, którzy deklarowali aktualne członkostwo w Towarzystwie. Osoby te stanowiły zaledwie 5,9\% ankietowanych, $\mathrm{z}$ czego najwięcej $(8,3 \%)$ pojawiło się ich w rejonie schroniska „Murowaniec” na Hali Gąsienicowej. Kwalifikacje osób deklarujących aktualne członkostwo w PTTK zostały ocenione dość wysoko, z czego najwyżej (podobnie jak w pozostałych omówionych wypadkach) — znajomość zachowania się na szlakach i w obiektach turystycznych $(4,8)$ oraz znajomość zasad bezpieczeństwa w turystyce pieszej górskiej $(4,8)$ (wykres 5). Wyżej od pozostałych oceniono także przygotowanie psychofizyczne do wyjazdu $(3,6)$. Co ciekawe, jedynie 1,4\% ankietowanych przyznało, że zdobywanie górskich odznak turystycznych PTTK stanowi dla nich motywację do wyjazdu i uznało je za „przeżytek poprzedniej epoki”. Jeśli chodzi o tę grupę respondentów, aż 66,6\% korzystało z noclegów w schroniskach górskich, a najczęściej odwiedzanymi rejonami Tatr były: Dolina Kościeliska i Kasprowy Wierch (po 54,5\%). W wypadku członków PTTK dużo większa była wiedza na temat samej turystyki kwalifikowanej - jedynie 33,3\% nie potrafiło udzielić informacji na ten temat.

Podsumowując, należy podkreślić, że mimo uzyskanego w badaniach dość zadowalającego poziomu kwalifikacji, z obserwacji własnych oraz danych TOPR wynika, że turyści piesi w Tatrzańskim Parku Narodowym często wykazują się brakiem przygotowania do wędrówki. Większość turystów odwiedzających polskie Tatry w sezonie letnim nie ma wiedzy na temat odwiedzanych rejonów, traktuje szlak górski jak ścieżkę spacerową o poziomie trudności charakterystycznym dla terenów nizinnych. Schronisko górskie staje się punktem docelowym wycieczki, traktowanym jako obiekt gastronomiczny — celem staje się możliwość zjedzenia posiłku, po którym z reguły następuje powrót tą samą drogą.

\section{Podsumowanie}

Tatrzański Park Narodowy to obszar o bardzo wyraźnej masowości ruchu turystycznego. Cenne walory przyrodnicze najwyższych gór Polski przyciągają co roku blisko 3 mln turystów, z czego przeważająca część przybywa w sezonie letnim. Jak wynika z przeprowadzonych badań sondażowych, a także obserwacji uczestniczących i analiz statystyk TOPR — góry te stają się przedmiotem aktywności dostępnej dla wszystkich, zatraciły zatem swój elitarny charakter, zarówno pod względem odwiedzających je osób, jak i ich kwalifikacji. Odwiedzający tereny górskie nie ma poczucia ewentualnego ryzyka — brakuje im świadomości i kultury turystycznej. Sondaż ankietowy, w którym analizie poddano kwalifikacje turystów pieszych odwiedzających TPN, ukazał jednak, że sami respondenci oceniają swoje umiejętności dość wysoko i często brawurowo, co ma przełożenie na działania ratownicze TOPR w ciągu całego roku, a zwłaszcza w sezonie letnim. Wyższe kwalifikacje charakteryzują osoby związane ze środowiskami turystyki kwalifikowanej - wspinające się lub przynależące do PTTK.

Podsumowując, należy podkreślić, że postmodernistyczna komercjalizacja sfery czasu wolnego, w tym popularyzacja przez media form rekreacji plenero- 
wej, przyczynia się do lekkomyślnych, często zuchwałych, a tym samym groźnych zachowań na szlakach wysokogórskich. Antidotum z pewnością stanowi szeroko rozumiana edukacja młodzieży, wychowanie do turystyki i czasu wolnego, a także popularyzacja idei turystyki kwalifikowanej, której wiele cech ma ponadczasowe znaczenie.

\section{Bibliografia}

Ciapała Sz., Zielonka T., Kmiecik-Wróbel J. (2010), Metody zapobiegania nielegalnej dyspersji turystów i związanej z nia erozji gleby w Tatrzańskim Parku Narodowym, „Folia Turistica”, nr 22, s. 67-89.

Czyż M. (2010), Dlaczego chodzimy po górach? Czyli o motywach uprawiania sportów wysokogórskich w świetle publikacji Jana Alfreda Szczepańskiego, „Folia Turistica”, nr 23, s. 241-255.

Fenczyn J. (2000), Motywy uprawiania turystyki górskiej przez studentów wyższych uczelni Krako$w a$, www.edukacyjne.dyskursy.univ.szczecin.pl.

Frydryczak B. (2007), Okiem turysty - pojęcie krajobrazu turystycznego, [w:] Kazimierczak M. (red.), Turystyka i podróżowanie w aksjologicznej perspektywie, Poznań, s. 99-108.

Łobożewicz T. (1983), Turystyka kwalifikowana, Warszawa.

Mała encyklopedia filozofii (2002), Jedynak S. (red.), Bydgoszcz-Lublin.

Merski J. (2002), Turystyka kwalifikowana, Warszawa.

Mokras-Grabowska J. (2007), Turystyka kwalifikowana — od idei do praktyki. Przykład turystów odwiedzających Tatrzański Park Narodowy, [w:] Wczoraj, dziś i jutro turystyki aktywnej i specjalistycznej, red. A. Stasiak, J. Śledzińska, B. Włodarczyk, wyd. PTTK, s. 347-357.

Niezgoda A. (2013), Wplyw mody na rozwój turystyki, [w:] Wspótczesne uwarunkowania i problemy rozwoju turystyki, Pawlusiński R. (red.), Kraków, s. 85-92.

Partyka J. (2010), Ruch turystyczny w polskich parkach narodowych, „Folia Turistica”, nr 22, s. $9-23$.

Pociask-Karteczka J., Baścik M., Czubernat S. (2007), Ruch turystyczny w Tatrzańskim Parku Narodowym w latach 1993-2005, [w:] Kurek W., Mika M., Studia nad turystyka. Tradycje, stan obecny i perspektywy badawcze, Kraków, s. 271-279.

Prószyńska-Bordas H. (2013), Zróżnicowanie cech osób wędrujących w sezonie bezśnieżnym po górach średnich $i$ niskich $w$ Polsce na przykładzie turystów odwiedzajacych wybrane parki narodowe, „Studia i Monografie AWF we Wrocławiu”, nr 118, s. 64-82.

Prus M. (2011), Tatrzański Park Narodowy i Park Narodowy Berchtesgaden — studium porównawcze zagospodarowania turystycznego, „Studia i Materiały CEPL w Rogowie”, 13, z. 3 (28), s. 74-80.

Stownik filozofii (2009), Hartman J. (red.), Kraków.

Stownik języka polskiego PWN (1981), red. R. Łąkowski, Warszawa.

Wolski D. (2001), Odpowiedzialność za bezpieczeństwo turysty na obszarze parku narodowego obejmującego tereny górskie, [w:] Nauka a zarządzanie obszarem Tatr i ich otoczeniem, t. 3, Zakopane, s. 75-83.

Góry, Literatura, Kultura 11, 2018

(C) for this edition by CNS 